SRNL-STI-2012-00523

SRNL-L3100-2012-00096

Revision 0

Keywords: Rotary microfilter, media, membrane, nuclear waste, SCIX

Retention: Permanent

\title{
Evaluation of Alternative Filter Media for the Rotary Microfilter, Phase 2
}

Mark D. Fowley

July 2012

Savannah River National Laboratory Savannah River Nuclear Solutions Aiken, SC 29808 contract number DE-AC09-08SR22470.

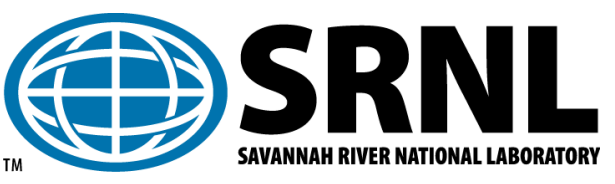


SRNL-L3100-2012-00096

Revision 0

\section{DISCLAIMER}

This work was prepared under an agreement with and funded by the U.S. Government. Neither the U.S. Government or its employees, nor any of its contractors, subcontractors or their employees, makes any express or implied:

1. warranty or assumes any legal liability for the accuracy, completeness, or for the use or results of such use of any information, product, or process disclosed; or

2. representation that such use or results of such use would not infringe privately owned rights; or

3. endorsement or recommendation of any specifically identified commercial product, process, or service.

Any views and opinions of authors expressed in this work do not necessarily state or reflect those of the United States Government, or its contractors, or subcontractors.

Printed in the United States of America

Prepared for U.S. Department of Energy 


\section{REVIEWS AND APPROVALS}

AUTHOR:

M. D. Fowley, Process Engineering Technology

Date

REVIEWER:

D. T. Herman, Advanced Characterization and Processing

Date

APPROVALS:

B. J. Giddings, Manager

Date

Process Engineering Technology

F. M Pennebaker, Manager

Date

Advanced Characterization and Processing

S. L. Marra, Manager

Date

Environmental \& Chemical Process Technology Research Programs 


\section{EXECUTIVE SUMMARY}

Testing was conducted at the Savannah River National Laboratory (SRNL) to investigate filter membrane performance in an effort to increase rotary microfilter (RMF) throughput. Membranes were tested in the SpinTek Filtration, Inc. Static Test Cell (STC), which permitted quick and easy testing of several different membranes. Testing consisted of 100 hours tests with two different slurry feeds, based on recommendations from the phase 1 testing [1]. One feed contained Monosodium Titanate (MST) solids in a simulated salt solution. The other feed contained simulated sludge batch 6 (SB6) solids in a simulated salt solution.

Five membranes were tested, one each from filter manufactures Pall and Porvair and three from the Oak Ridge National Laboratory (ORNL). The membrane from Pall is the current membrane used on the latest generation RMF. The Porvair membrane performed well in previous STC tests [1] as well as one of the ORNL membranes. The other two membranes from ORNL were recently developed and not available for the previous STC test.

The results indicate that the Porvair filter performed best with the MST slurry and the ORNL SVB6-1B filter performed best with the SB6 slurry. Difficulty was encountered with the ORNL filters due to their dimensional thickness, which was greater than the recommended filter thickness for the STC. The STC equipment was modified to complete the testing of the ORNL filters. 
TABLE OF CONTENTS

Revision 0

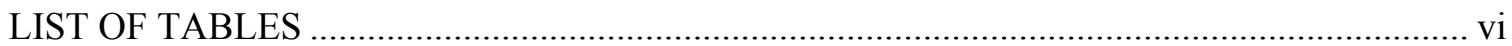

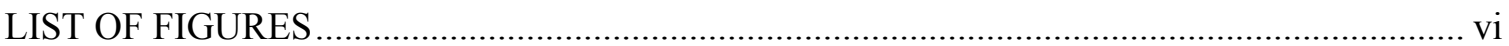

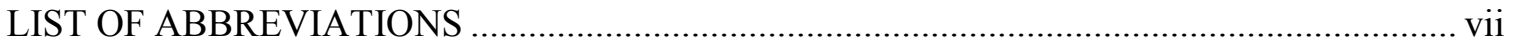

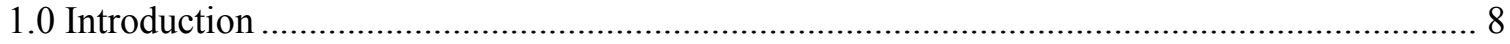

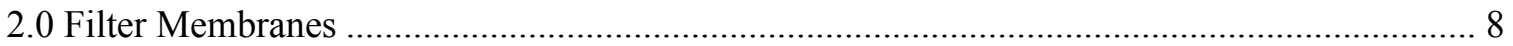

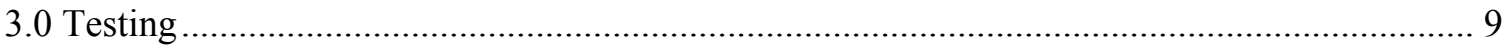

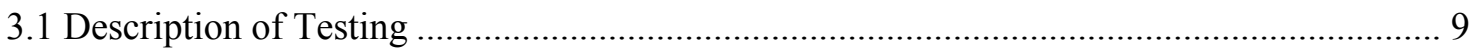

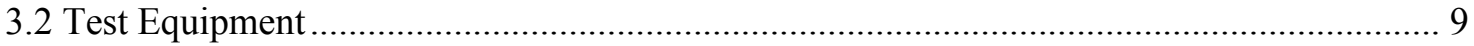

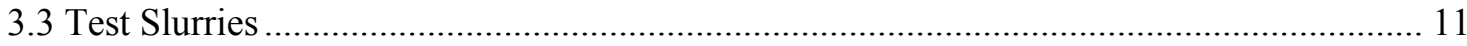

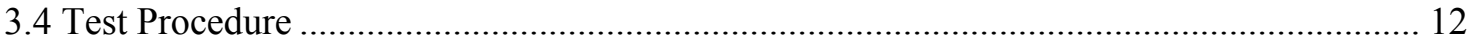

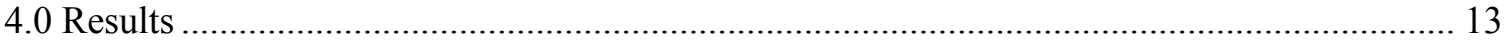

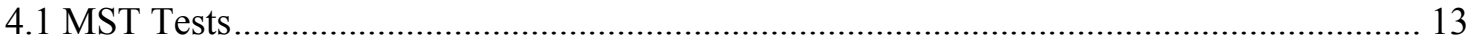

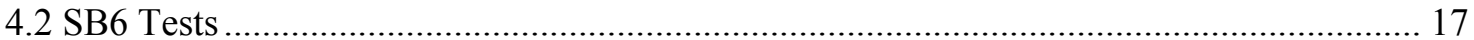

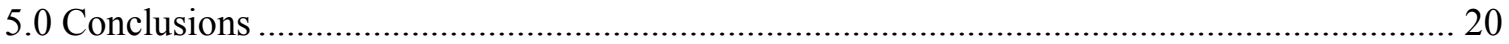

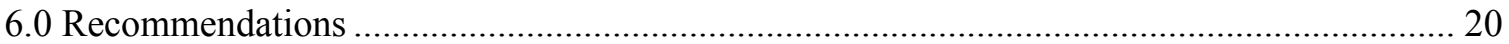

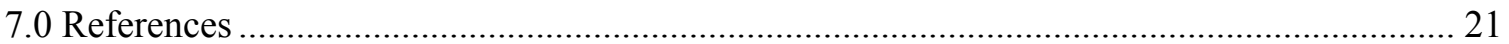

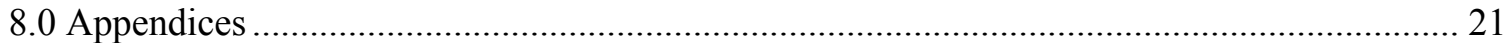




\section{LIST OF TABLES}

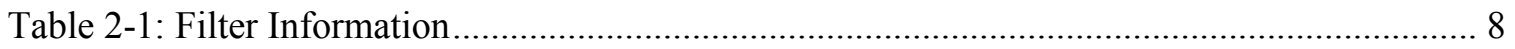

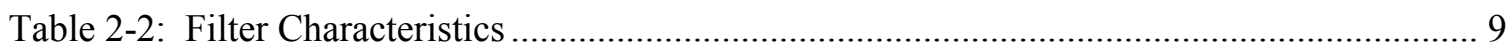

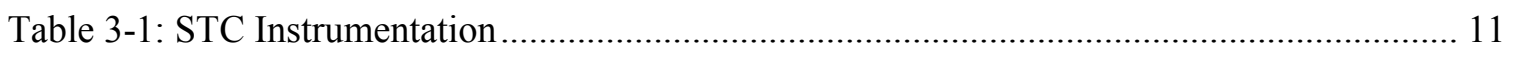

Table 3-2: Simulated Supernate Solution Recipe (Tank 37H) .................................................. 11

Table 3-3: Expected Anion/Cation Content of Sludge Feed Simulants ...................................... 12

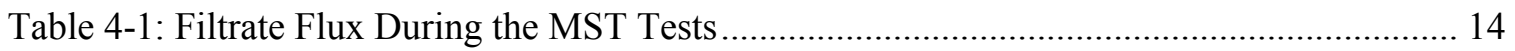

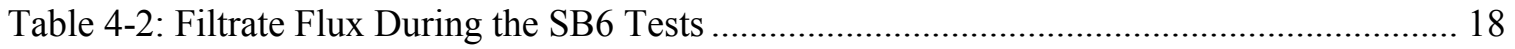

\section{LIST OF FIGURES}

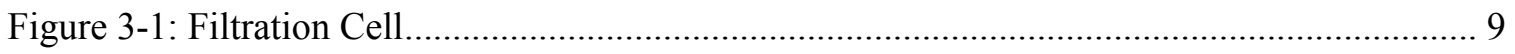

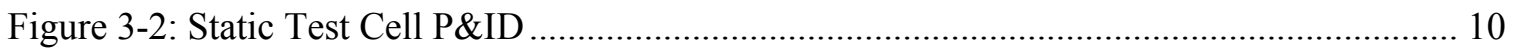

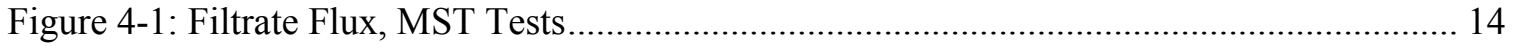

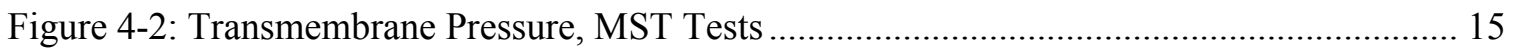

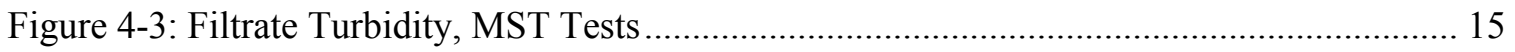

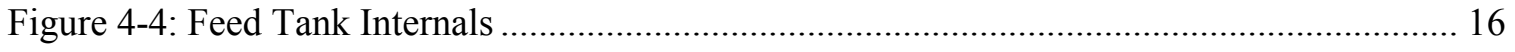

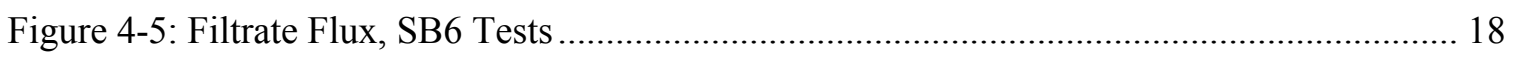

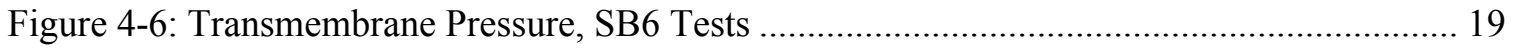

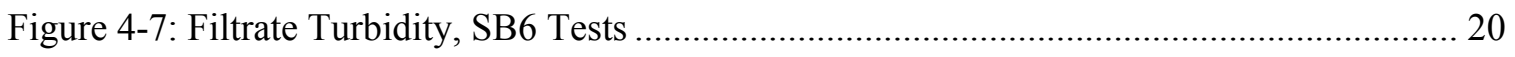

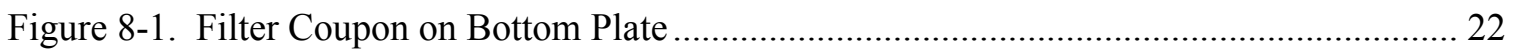

Figure 8-2. Gaskets at Edge and Center to Aid Sealing .......................................................... 23

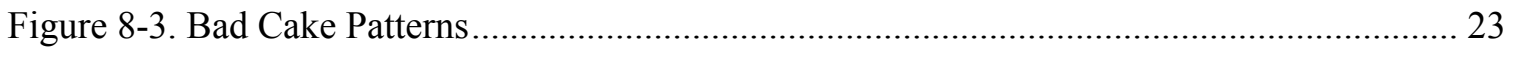

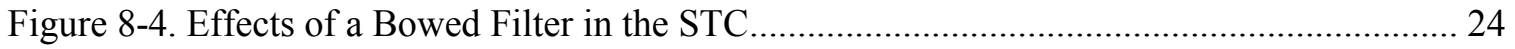

Figure 8-5. Final Gasket Configuration for ORNL Filters .................................................. 24 


\section{LIST OF ABBREVIATIONS}

$\begin{array}{ll}\text { DI } & \text { deionized } \\ \text { DOE } & \text { Department of Energy } \\ \text { EM } & \text { Environmental Management } \\ \text { gpm } & \text { gallons per minute } \\ \text { HMI } & \text { human machine interface } \\ \text { lpm } & \text { liters per minute } \\ \text { mlpm } & \text { milliliters per minute } \\ \text { MST } & \text { monosodium titanate } \\ \text { NTU } & \text { Nephelometric Turbidity Unit } \\ \text { ORNL } & \text { Oak Ridge National Laboratory } \\ \text { PID } & \text { Process and Instrumentation Drawing } \\ \text { PLC } & \text { Process level Controller } \\ \text { psig } & \text { pounds per square inch, gauge } \\ \text { QA } & \text { Quality Assurance } \\ \text { RCRA } & \text { Resource Conservation and Recovery Act } \\ \text { RMF } & \text { rotary microfilter } \\ \text { rpm } & \text { revolutions per minute } \\ \text { SB6 } & \text { Sludge Batch 6 } \\ \text { SRNL } & \text { Savannah River National Laboratory } \\ \text { SRS } & \text { Savannah River Site } \\ \text { SS } & \text { stainless steel } \\ \text { STC } & \text { static test cell } \\ \text { TMP } & \text { transmembrane pressure } \\ \text { USB } & \text { Universal Serial Bus }\end{array}$


SRNL-STI-2012-00523

SRNL-L3100-2012-00096

Revision 0

\subsection{Introduction}

The Savannah River National Laboratory (SRNL), under the Department of Energy (DOE) Office of Environmental Management (EM), has conducted testing to improve the throughput of the Rotary Microfilter (RMF) Ultrafiltration System. It was believed that filter performance could be improved by using a better filter membrane.

The testing described in this report is a continuation of testing described in report SRNL-STI2011-00522, rev. 0, Evaluation of Alternative Filter Media for the Rotary Microfilter, where several different membranes were evaluated. The high performing membranes from that testing, in addition to two new membranes, were subjected to long duration testing to compare performance.

The Static Test Cell (STC), made by SpinTek Filtration, Inc., was used for this testing. As the name implies, the filtration method is stationary using a method similar to cross-flow filtration. Although different in the dynamic aspects of a rotary filter, the STC provided a means of quickly and easily comparing filter membranes for potential RMF deployment.

\subsection{Filter Membranes}

Five different filter coupons were tested in the STC, two commercially available membranes (Pall PMM050 and Porvair Sinterflo F3) and three from the ORNL Inorganic Membrane Group (designated as SVB3-11B, SVB6-1B and SVB6-14C). Details of the coupons are listed in Table 2-1 and specific information about the ORNL coupons is listed in Table 2-2. Three of the membranes were tested in phase 1 [1] of this task and performed well enough to warrant further testing (PMM050, Sinterflo F3 and SVB6-1B). The remaining two were recently developed for this phase of testing.

The Pall filter was a sintered stainless steel membrane on a stainless steel mesh and is the baseline membrane for the RMF. The Porvair filter was a sintered stainless steel fiber membrane. The SVB3-11B and SVB6-14C membranes were composed of a ceramic membrane on top of a stainless steel support structure. The SVB6-1B membrane was a sintered stainless steel fiber membrane on a stainless steel support structure.

Table 2-1: Filter Information

\begin{tabular}{|l|l|l|l|l|}
\hline Filter & Manufacture & Description & Pore Size $(\mu \mathrm{m})$ & Comments \\
\hline PMM050 & Pall & Sintered SS & 0.5 nominal & N/A \\
\hline Sinterflo F3 & Porvair & $\begin{array}{l}\text { Sinter bonded SS } \\
\text { metal fibers }\end{array}$ & 3.0 absolute & N/A \\
\hline SVB6-1B & ORNL & $316 \mathrm{~B}+$ Atmix & 0.5 nominal & $\begin{array}{l}\text { Fine porous metal } \\
\text { layers on support }\end{array}$ \\
\hline SVB3-11B & ORNL & $\begin{array}{l}316 \mathrm{~B}+\mathrm{Atmix}^{*}+ \\
\text { Atmix }{ }^{*}-\mathrm{TiO}_{2}\end{array}$ & $<0.3$ nominal & $\begin{array}{l}\text { Ceramic metal } \\
\text { composite layer }\end{array}$ \\
\hline SVB6-14C & ORNL & $\begin{array}{l}316 \mathrm{~B}+\mathrm{Atmix}^{*}- \\
\mathrm{TiO}_{2}+\text { Atmix }^{*}-\mathrm{TiO}_{2}\end{array}$ & $<0.5$ nominal & $\begin{array}{l}\text { Ceramic metal } \\
\text { composite layer }\end{array}$ \\
\hline
\end{tabular}

Fine Stainless Steel particles produced by the Atmix Corporation 
SRNL-STI-2012-00523

SRNL-L3100-2012-00096

Revision 0

Table 2-2: Filter Characteristics

\begin{tabular}{|l|l|l|l|l|}
\hline Filter & $\begin{array}{l}\text { Thickness } \\
\text { (in) }\end{array}$ & $\begin{array}{l}\text { Bubble Point Range } \\
(\mathrm{psi})^{2}\end{array}$ & $\begin{array}{l}\text { Gas Permeance } \\
\left(\mathrm{cm}^{3} / \mathrm{cm}^{2}-\mathrm{min}-\mathrm{cm}\right. \\
\mathrm{Hg})\end{array}$ & $\begin{array}{l}\text { Liquid } \\
\text { Permeability } \\
\left(\mathrm{gpm} / \mathrm{ft}^{2}\right)\end{array}$ \\
\hline SVB6-1B & 0.60 & $6.5-12.5$ & 1.3 & $5.1 @ 40 \mathrm{psi}$ \\
\hline SVB3-11B & 0.69 & $9-28$ & N/A & N/A \\
\hline SVB6-14C & 0.68 & $9-18$ & N/A & N/A \\
\hline
\end{tabular}

1. Average thickness measured at 4 locations.

2. Pressure range from observation of first bubble to uniform bubbling along the entire filter using isopropanol.

\subsection{Testing}

\subsection{Description of Testing}

The 5 filters were subjected to two series of extended duration (100 hours) filtration tests using the STC equipment. One series of tests used slurry composed of 1 weight $\%$ monosodium titanate (MST) in a simulated salt solution and the other used slurry composed of 1 weight $\%$ Sludge Batch 6 (SB6) sludge simulant [2] in a simulated salt solution. Filtrate flux (filtrate flow per unit area) was compared to evaluate filter performance.

\subsection{Test Equipment}

The STC is a compact, stainless steel filtration unit for testing flat sheet filter elements, or coupons. The recommended size of the filter sheet, or coupon, was 4.25 " $\mathrm{x} 3$ " and less than 0.005 " thick. The central part of the STC is the filtration cell, which consisted of two mating plates that housed the filter membrane (Figure 3-1).

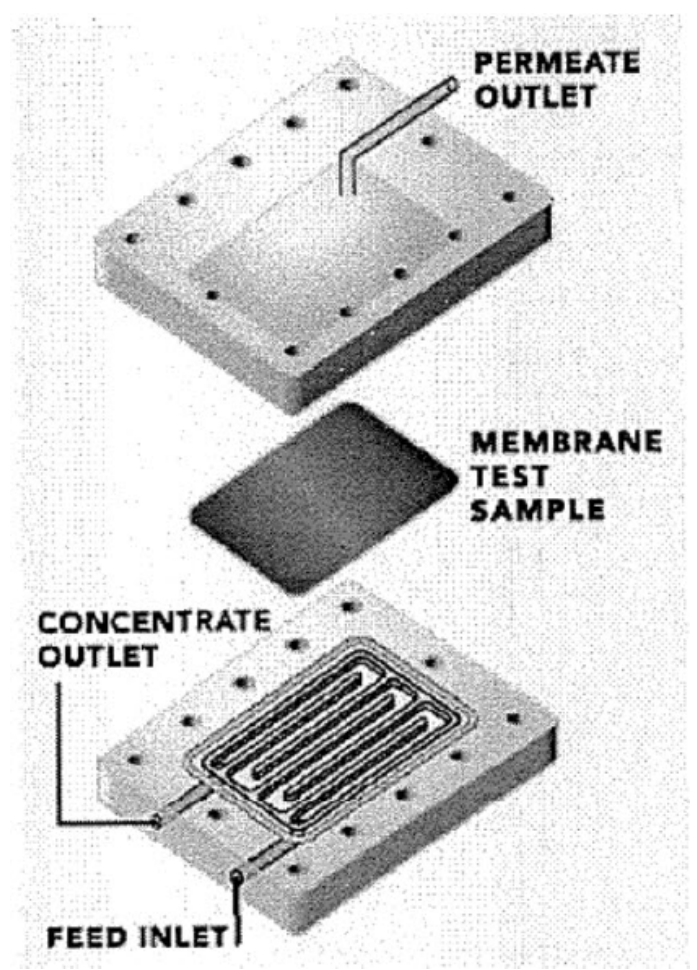

Figure 3-1: Filtration Cell 
SRNL-STI-2012-00523

SRNL-L3100-2012-00096

Revision 0

Feed was pumped from a feed tank to the cell with a progressive cavity pump having a capacity of $3.8 \mathrm{lpm}(1 \mathrm{gpm})$. Optimal feed flow rate was between 3.0 and $3.8 \mathrm{lpm}(0.8-1.0 \mathrm{gpm})$ and optimal pressure was 40-60 psig measured at the cell inlet. Operating conditions were controlled with throttle valves and a Programmable Logic Controller (PLC) that regulated the pump speed.

The feed flowed into the bottom plate and through a serpentine, rectangular channel that was 0.327 inches wide, 0.107 inches deep and 22.875 inches in length. The total effective surface area of the filter exposed to flow in the channel was $0.05 \mathrm{ft}^{2}$. Given the dimensions of the STC channel and a flow rate of $3.8 \mathrm{lpm}(1 \mathrm{gpm})$ the velocity through the channel would be $2.2 \mathrm{~m} / \mathrm{s}$ ( 7.3 $\mathrm{ft} / \mathrm{s}$ ), which is comparable to typical cross-flow filters. In contrast, the linear speed of the RMF at the outer filter edge is $15.8 \mathrm{~m} / \mathrm{s}(52 \mathrm{ft} / \mathrm{s})$ and the speed at the hub is $4.9 \mathrm{~m} / \mathrm{s}(16 \mathrm{ft} / \mathrm{s})$.

Concentrate exited the channel out of the bottom plate at the end of the channel and passed through a heat exchanger where it was cooled then recycled back to the feed tank. The filtrate passed from the channel through the membrane into a cavity in the upper plate where it exited the cell. The filtrate flow was directed to either the feed tank for recycling or to a sample port with a three way valve.

A Process and Instrumentation Drawing (PID) of the STC is shown in Figure 3-2. The feed tank agitator was an add-on to the SpinTek hardware to enhance the mixing in the feed tank.

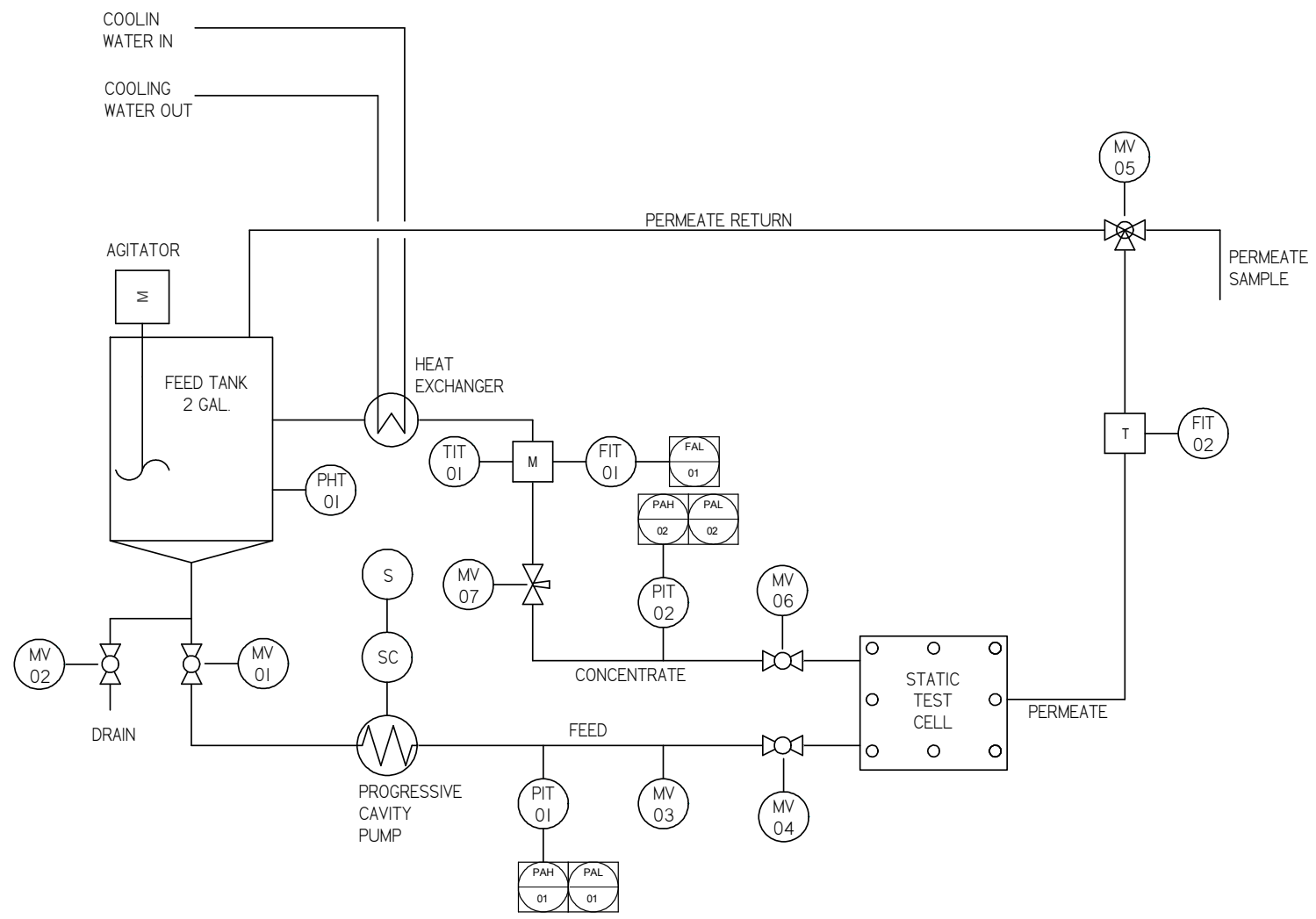

Figure 3-2: Static Test Cell P\&ID 
SRNL-STI-2012-00523

SRNL-L3100-2012-00096

Revision 0

Instrumentation for the STC is listed in Table 3-1. Concentrate and filtrate flow were measured with magnetic flow meters. Pressure was measured at the feed inlet to the cell and at the concentrate exit of the cell. Temperature was measured in the concentrate magnetic flow meter. The instruments were calibrated per SRNL Quality Assurance (QA) protocol prior to testing. Motor speed and motor load were recorded by the PLC.

Table 3-1: STC Instrumentation

\begin{tabular}{|l|l|l|l|l|}
\hline $\begin{array}{l}\text { PID } \\
\text { Label }\end{array}$ & Description & P/N & Range & Tolerance $^{1}$ \\
\hline FIT01 & $\begin{array}{l}\text { ifm electronic Magnetic Flow Sensor } \\
\text { with Temperature Sensor }\end{array}$ & SM6004 & $0.1-25 \mathrm{lpm}$ & $+/-0.63 \mathrm{lpm}$ \\
\hline FIT02 & ifm electronic Volumetric Flow Sensor & SQ0500 & $0-200 \mathrm{mlpm}$ & $+/-21 \mathrm{mlpm}$ \\
\hline PIT01 & ifm electronic Pressure Sensor & PI1694 & $0-60 \mathrm{psig}$ & $+/-0.54 \mathrm{psig}$ \\
\hline PIT02 & ifm electronic Pressure Sensor & PI1694 & $0-60 \mathrm{psig}$ & $+/-0.54 \mathrm{psig}$ \\
\hline TIT01 & $\begin{array}{l}\text { ifm electronic Magnetic Flow Sensor } \\
\text { with Temperature Sensor }\end{array}$ & SM6004 & $-20-80{ }^{\circ} \mathrm{C}$ & $+/-1.5{ }^{\circ} \mathrm{C}$ \\
\hline N/A & HF Scientific Turbidimeter & Micro 100 & $0-1000 \mathrm{NTU}$ & $+/-0.12 \mathrm{NTU}^{2}$ \\
\hline
\end{tabular}

2. At 0.10 NTU.

Alarms for feed flow, high inlet pressure and high outlet pressure were set on the human machine interface (HMI). Alarm messages would pop up on the HMI screen when the system reached a set point and would require user attention and system adjustment to clear.

\subsection{Test Slurries}

The phase 2 testing used two feed slurries from the phase 1 test campaign to evaluate the performance of the filter coupons. The first contained 1 weight \% MST in simulated Savannah River Site (SRS) salt solution and the second contained 1 weight \% simulated SB6 in simulated SRS salt solution. Table 3-2 shows the composition of the simulated SRS salt solution, which represents the supernate in Tank $37 \mathrm{H}$.

Table 3-2: Simulated Supernate Solution Recipe (Tank 37H)

\begin{tabular}{|l|l|}
\hline Species & Concentration (molar) \\
\hline $\mathrm{Na}^{+}$ & 6.44 \\
\hline $\mathrm{NO}_{3}{ }^{-}$ & 2.26 \\
\hline $\mathrm{NO}_{2}{ }^{-}$ & 0.74 \\
\hline $\mathrm{OH}^{-}$ & 2.57 \\
\hline $\mathrm{AlO}_{2}{ }^{-}$ & 0.35 \\
\hline $\mathrm{CO}_{3}{ }^{-2}$ & 0.11 \\
\hline $\mathrm{SO}_{4}{ }^{-2}$ & 0.15 \\
\hline $\mathrm{SiO}_{3}{ }^{-2}$ & 0.004 \\
\hline \multicolumn{2}{|c|}{ 1. Based on SRS average salt solution. } \\
\hline
\end{tabular}

MST is a material used at the SRS to adsorb actinides and strontium. The RMF will be subjected to MST once it is in service and these tests were conducted to determine the performance of the filters with MST. The MST was provided by Harrell Industries, Inc. as a 15 weight \% slurry. The batch used was from pail number 11 of 74, lot number 082709 loaded on 9/24/2009. 
SRNL-STI-2012-00523

SRNL-L3100-2012-00096

Revision 0

The SB6 was a non-RCRA solution simulating the sludge in the SRS tank 40. The simulated Sludge Batch 6-DS slurry was provided by Optima, sample number 167792, batch number 10QAB-0443, produced on 4/5/2010. Table 3-3 shows the composition and properties of the simulated SB6 slurry.

Table 3-3: Expected Anion/Cation Content of Sludge Feed Simulants

\begin{tabular}{|c|c|}
\hline Component & Concentration (wt \% dry) \\
\hline \multicolumn{2}{|l|}{ Cations } \\
\hline Aluminum, $\mathrm{Al}$ & 9.59 \\
\hline Calcium, $\mathrm{Ca}$ & 2.11 \\
\hline Copper, $\mathrm{Cu}$ & 0.13 \\
\hline Iron, $\mathrm{Fe}$ & 24.34 \\
\hline Potassium, $\mathrm{K}$ & 0.005 \\
\hline Magnesium, $\mathrm{Mg}$ & 0.12 \\
\hline Manganese, Mn & 2.73 \\
\hline Sodium, $\mathrm{Na}$ & 7.20 \\
\hline Nickel, Ni & 2.79 \\
\hline Silicon, Si & 0.76 \\
\hline Strontium, Sr & 0.09 \\
\hline Zinc, $\mathrm{Zn}$ & 0.27 \\
\hline \multicolumn{2}{|l|}{ Anions } \\
\hline Carbonate, $\mathrm{CO}_{3}{ }^{2-}$ & 5.13 \\
\hline Nitrite, $\mathrm{NO}_{2}^{-}$ & 5.87 \\
\hline Nitrate, $\mathrm{NO}_{3}^{-}$ & 1.95 \\
\hline Total Hydroxide, $\mathrm{OH}^{-}$ & 24.7 \\
\hline Oxide, $\mathrm{O}^{2-}$ & 11.4 \\
\hline Phosphate, $\mathrm{PO}_{4}{ }^{3-}$ & 0.13 \\
\hline Sulfate, $\mathrm{SO}_{4}{ }^{2-}$ & 0.64 \\
\hline \multicolumn{2}{|l|}{ Properties } \\
\hline Specific Gravity & 1.1 \\
\hline Total Solids, wt. \% & 16.0 \\
\hline Soluble Solids, wt. \% & 3.0 \\
\hline TOC (wet) & $<0.05$ \\
\hline
\end{tabular}

\subsection{Test Procedure}

Each filter was subjected to two 100 hour tests, one with each slurry. A 100 hour test was performed as follows. The filter coupon was installed in the filtration cell and the test slurry was added to the feed tank. The feed tank mixer was started and then the chiller for the heat exchanger. The control logic was entered into the HMI. The STC had two modes of automatic control: feed pressure or concentrate flow rate. It was determined during testing that controlling by feed pressure initially then switching to concentrate flow after the flux began to stabilize provided the best results. A USB drive for collecting data was then inserted into the HMI port and a $\log$ rate was set. The isolation valves for the feed and concentrate lines were opened and the three way valve for the filtrate was closed (middle position).

The feed pump was started and the concentrate throttle valve was adjusted to obtain the desired transmembrane pressure (TMP). TMP was defined as the average pressure applied to the slurry side of the filter as measured by the feed pressure and the concentrate pressure. The filtrate, and 
SRNL-STI-2012-00523

SRNL-L3100-2012-00096

Revision 0

hence the test, was started by switching the three way filtrate valve to the feed tank. As the filter collected cake, the concentrate throttle valve was adjusted to maintain the desired TMP. The turbidity of the filtrate samples was measured at various times during the 100 hour test. Filtrate samples were acquired by turning the three way filtrate valve to the sample position.

The concentrate flow rate was typically maintained at or above $3.0 \mathrm{lpm}$, which was similar to the phase 1 testing. This rate provided a velocity in the concentrate return tubing that prevented the heavy MST particles from settling. Test parameters such as feed tank mixer speed, the feed flow rate, and the TMP were held consistent through individual tests and from test to test to assure comparability.

At the end of 100 hours, the test was stopped by stopping the feed pump and closing the feed and concentrate isolation valves. In addition, the three way filtrate valve was placed in the middle (closed) position to isolate the cell. The HMI was de-energized and the top plate of the cell was removed to inspect the filter. The cake was removed from the filter and returned to the feed tank and the filter was wiped clean and rinsed with de-ionized (DI) water. The filter was further cleaned using the following sequence: soak in DI water, soak in 2 molar nitric acid, rinse with DI water, soak in 1 molar sodium hydroxide, and rinse with DI water. The soaking steps were for 10 minutes or more.

\subsection{Results}

\subsection{MST Tests}

The results from the MST tests are presented in Figure 4-1, Figure 4-2, and Figure 4-3. Figure 4-1 shows the flux of each filter coupon where the flux is defined as the filtrate flow rate per unit area of the filter. Figure 4-1 includes an inset of the first 12 hours to provide more detail of initial flux readings. Figure 4-2 shows the TMP throughout the test. TMP was maintained at approximately 34 psig, as it was in phase 1 testing. Figure 4-3 shows the turbidity measurement of the filtrate taken at various times during the test.

Considering filtrate flux as a measure of performance, the Porvair filter out-performed the other filters; with the Pall PMM050 performing second best followed by the ORNL filters SVB6-14C and SVB6-1C, respectively. The filtrate flux at various times during each test is listed in Table 41 for direct comparison. From Table 4-1 the Porvair performed $15-31 \%$ better than the Pall and $27-53 \%$ better than the closest ORNL filter. These results are similar to phase 1 (40 psig inlet pressure testing) in that the Porvair provided the greatest filtrate flux with the MST slurry. 
SRNL-STI-2012-00523

SRNL-L3100-2012-00096

Revision 0

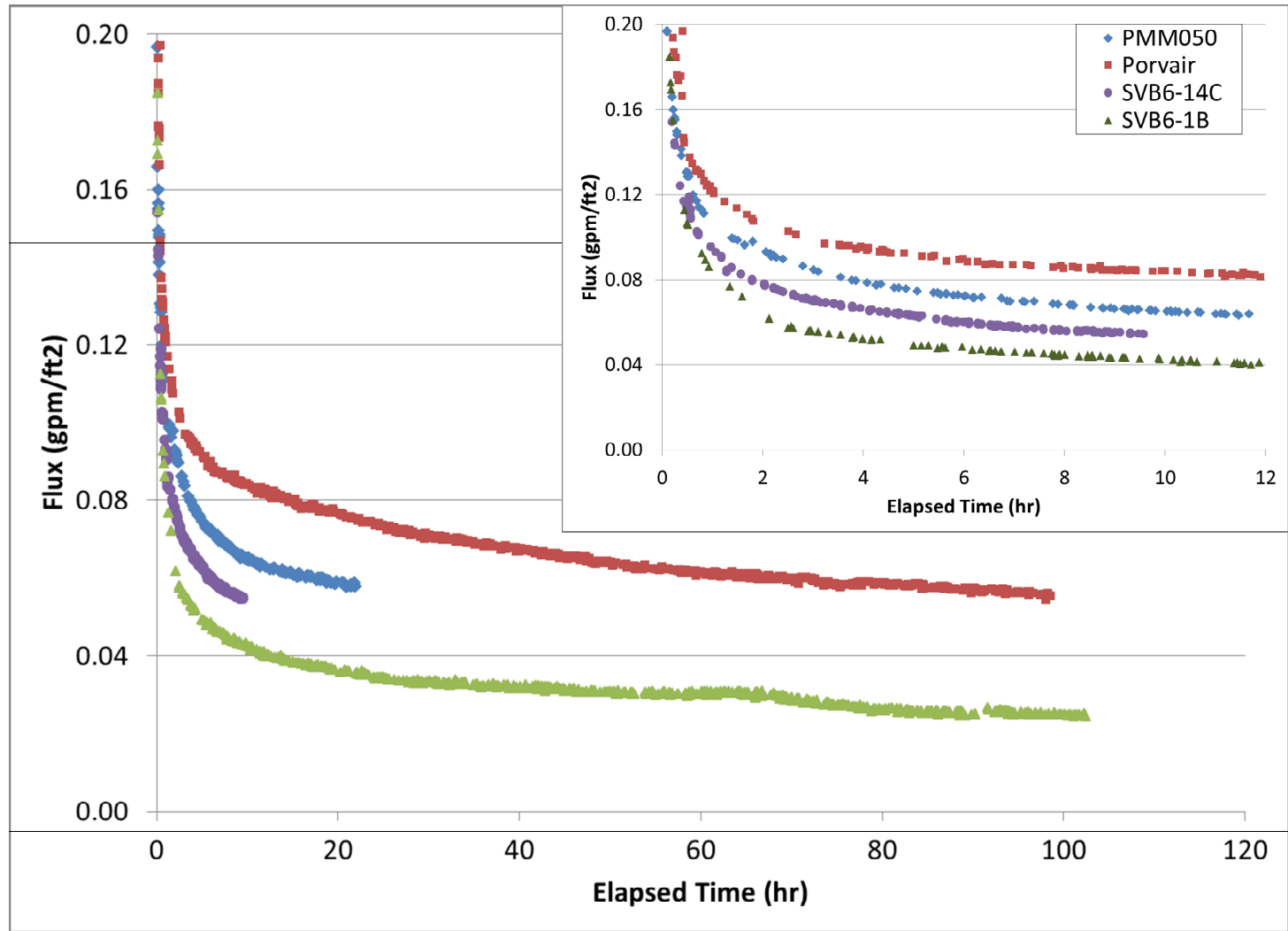

Figure 4-1: Filtrate Flux, MST Tests

Table 4-1: Filtrate Flux During the MST Tests

\begin{tabular}{|c|c|c|c|c|c|}
\hline Filter & \multicolumn{5}{|c|}{ Flux $\left(\mathrm{gpm} / \mathrm{ft}^{2}\right)$} \\
& $1 \mathrm{hr}$ & $10 \mathrm{hrs}$ & $20 \mathrm{hrs}$ & $50 \mathrm{hrs}$ & $100 \mathrm{hrs}$ \\
\hline Porvair $3 \mu$ & 0.122 & 0.084 & 0.077 & 0.064 & 0.055 \\
\hline PMM050 & 0.107 & 0.065 & 0.059 & N/A & N/A \\
\hline SVB6-14C & 0.096 & 0.055 & N/A & N/A & N/A \\
\hline SVB6-1B & 0.086 & 0.043 & 0.036 & 0.031 & 0.025 \\
\hline SVB3-11B & N/A & N/A & N/A & N/A & N/A \\
\hline
\end{tabular}

1. The SVB3-11B test was not acceptable due to poor flow conditions in the STC cell, see appendix 1.

Figure 4-2 shows that the TMP for each test was relatively similar and constant. Figure 4-3 shows that the turbidity of the filtrate from each test was less than 1 NTU, which indicated that the MST slurry was effectively filtered. 
SRNL-STI-2012-00523

SRNL-L3100-2012-00096

Revision 0

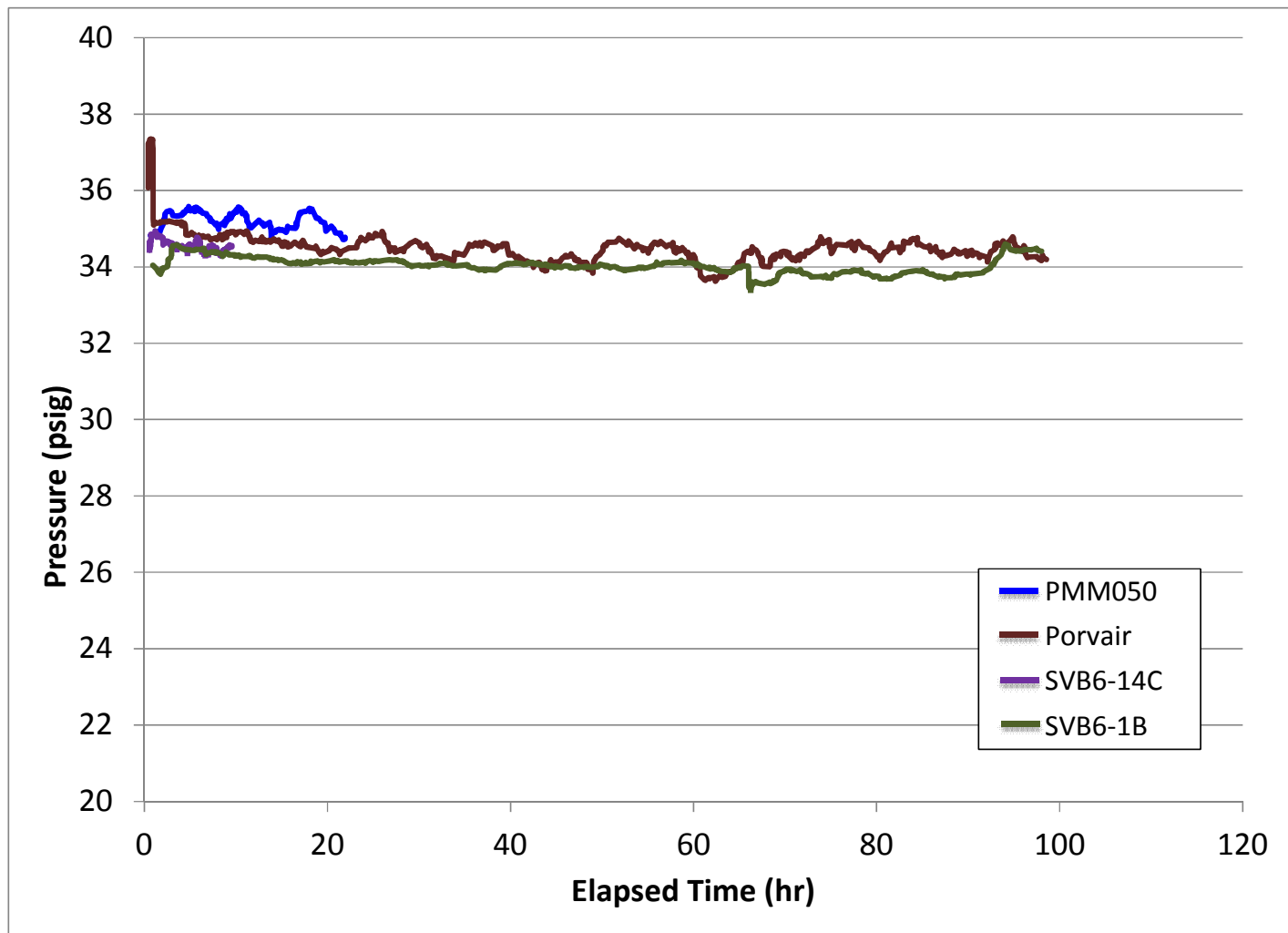

Figure 4-2: Transmembrane Pressure, MST Tests

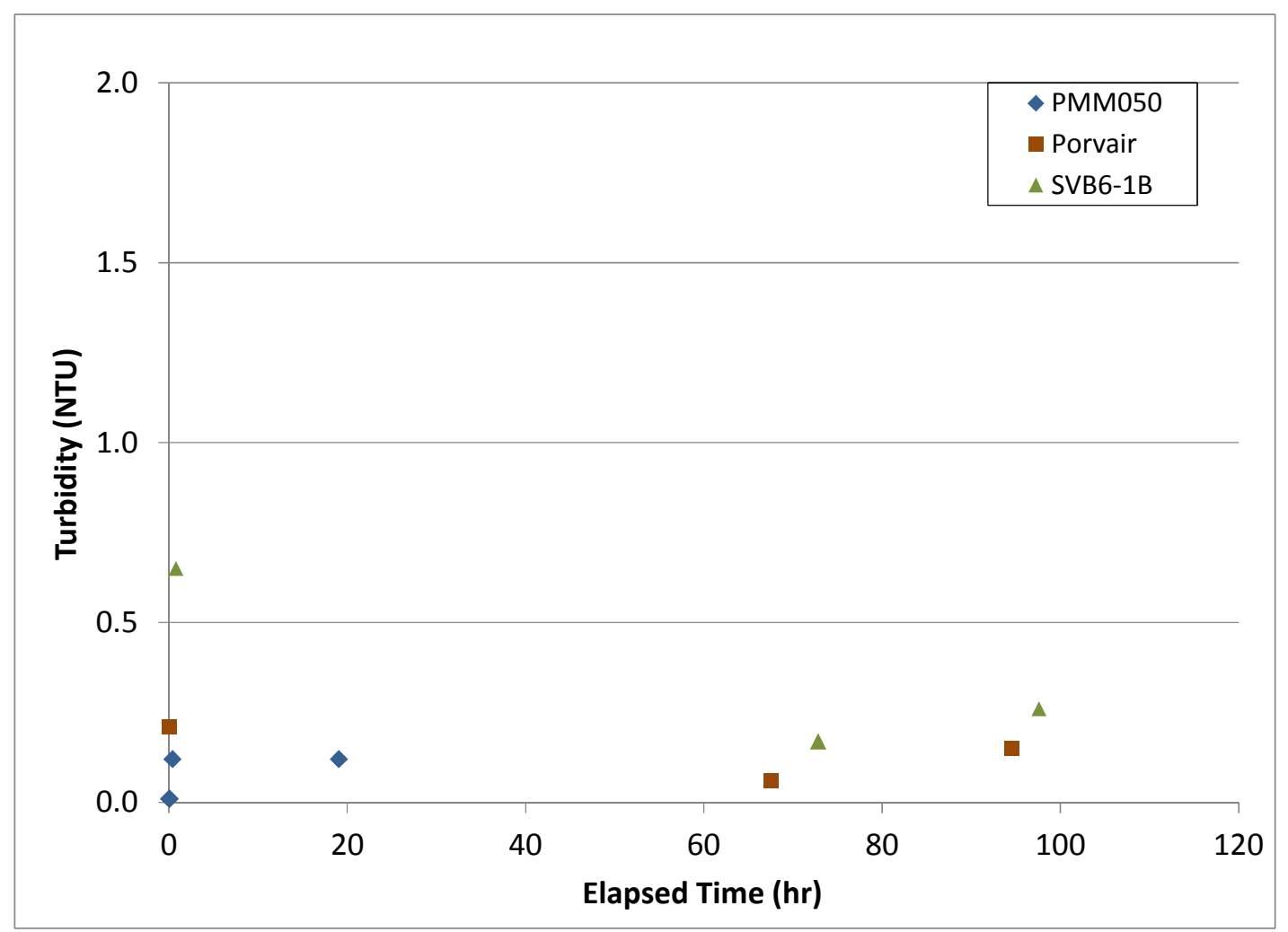

Figure 4-3: Filtrate Turbidity, MST Tests 
On a separate note, the limited results in Figure 4-1 and Table 4-1 indicate a problem with completing and/or conducting tests with MST. MST was a challenging solid to filter, however, the problems encountered with the MST testing was more a factor of the STC hardware than the solids. Issues occurred with feed tank mixing and with integrating the thick ORNL filters into the test cell.

Inadequate feed tank mixing became apparent in the initial stages of the MST testing. Mixing in the tank was designed to be provided by the directional discharge of the concentrate. The fast settling MST solids proved to be too difficult for the concentrate discharge jets to suspend. It was observed that large deposits of MST solids settled on the bottom of the feed tank in areas of low flow (areas where eddies occurred). Eddies were created by in-tank internals such as the $\mathrm{pH}$ probe and the concentrate discharge tubes (see Figure 4-4). To aid in mixing, an external laboratory mixer using a 2" diameter, airfoil type impeller was added. The rotational speed of $350 \mathrm{rpm}$ was observed to provide an adequate level of mixing.

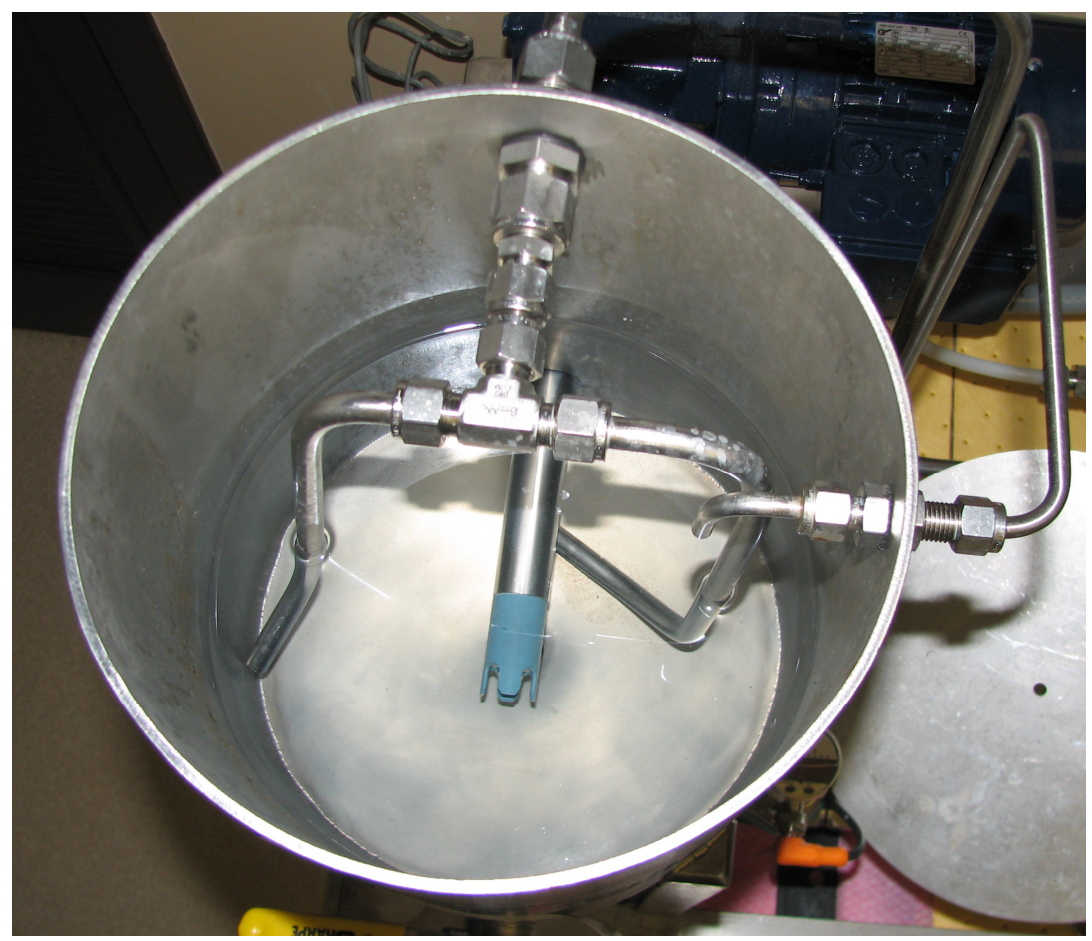

Figure 4-4: Feed Tank Internals

Integrating the thick ORNL filters (nominally $\sim 0.065$ " thick) into the STC, which specified 0.005 " thick filters or less, was problematic. Appendix 1 details the difficulty of the integration. An additional gasket was required with the ORNL filters to seal the top and bottom plates of the cell. Leakage through the additional gasket was an occasional problem.

Additionally, some the ORNL filters were not perfectly flat, that is, a few filters had some degree of curvature along their length or width. In some cases the curvature created a gap between the lower cell plate and the filter, which allowed feed to flow over the top of the channel walls to produce an undesirable flow pattern along the surface of the filter. Preferential flow over the 
SRNL-STI-2012-00523

SRNL-L3100-2012-00096

Revision 0

walls starved flow through the channels and allowed solids to build up in the channels. Several MST tests were conducted with different gasket configurations to find an arrangement that would both seal the cell and force the curved filter flat. In the end, a gasket configuration was found that provided good results, however, the solution was found after the MST testing. This made the ORNL test results questionable, and therefore, an effort was made to qualify the results by looking closer at not only the data but also physical aspects of the test.

Three things were considered when qualifying the ORNL MST data; solids buildup in the channels, the filter cake pattern, and trends from phase 1 testing [1]. The buildup of solids in the channels, which mostly occurred in the $180^{\circ}$ turns at the ends of the channels, was the primary indicator of a problem. In some cases the solids completely blocked the channel. Additional consideration was given to the duration of the test. The solids buildup in short tests may not have been sufficient enough to indicate a problem. Therefore, the pattern of the filter cake was used as a secondary indicator, that is, a defined wall imprint and a uniform cake on the filter was desirable. And third, the trends from the phase 1 testing were considered; the relative performance between the filters was expected to be similar. Comparison was complicated because phase 1 methodology was different than phase 2 . The phase 1 tests lasted about 1 hour and the cell inlet pressure was purposely changed midway during a test from a lower pressure (20 psig) to a higher pressure ( $40 \mathrm{psig}$ ). The $40 \mathrm{psig}$ results were most comparable to phase 2 . The ORNL test results presented in this section were judged to be acceptable given the considerations listed above.

\subsection{SB6 Tests}

The results from the SB6 tests are shown in Figure 4-5, Figure 4-6, and Figure 4-7. Figure 4-5 shows the filtrate flux, Figure 4-6 shows the TMP and Figure 4-7 shows the turbidity measurements of each test. 
SRNL-STI-2012-00523

SRNL-L3100-2012-00096

Revision 0

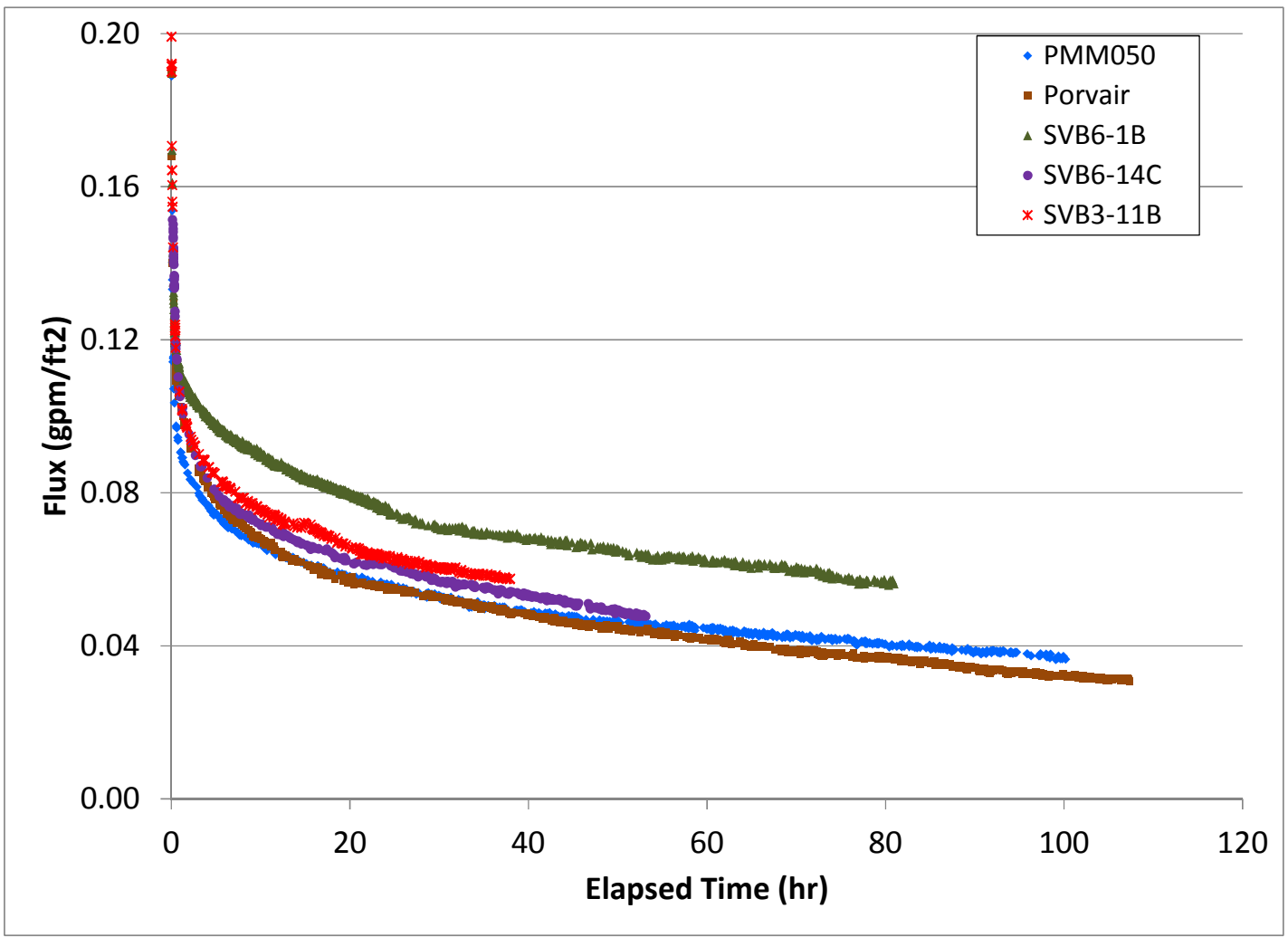

Figure 4-5: Filtrate Flux, SB6 Tests

The ORNL SVB6-1B filter out-performed the other filters. The SVB3-11B and SVB6-14C filters came in second and third, respectively, followed by the Porvair and Pall filters. The filtrate flux at various times during each test is listed in Table 4-2. From the table the SVB6-1B performed 7$21 \%$ better than the next best ORNL filter, $9-44 \%$ better than the Porvair filter and $22-38 \%$ better than the baseline Pall filter.

These results are contrary to the phase 1 results which indicated that the Porvair out-performed the Pall and ORNL filters. At this time there is no explanation for the disagreement in the phase 1/phase 2 SB6 results considering the general agreement between MST results.

Table 4-2: Filtrate Flux During the SB6 Tests

\begin{tabular}{|c|c|c|c|c|c|}
\hline Filter & \multicolumn{5}{|c|}{ Flux $\left(\mathrm{gpm} / \mathrm{ft}^{2}\right)$} \\
& $1 \mathrm{hr}$ & $10 \mathrm{hrs}$ & $20 \mathrm{hrs}$ & $50 \mathrm{hrs}$ & $100 \mathrm{hrs}$ \\
\hline Porvair 3 $\mu$ & 0.102 & 0.068 & 0.056 & 0.045 & 0.032 \\
\hline PMM050 & 0.091 & 0.067 & 0.058 & 0.047 & 0.037 \\
\hline SVB6-1B & 0.111 & 0.091 & 0.079 & 0.065 & - \\
\hline SVB3-11B & 0.104 & 0.075 & 0.067 & - & - \\
\hline SVB6-14C & 0.104 & 0.072 & 0.062 & 0.050 & - \\
\hline
\end{tabular}

Figure 4-6 shows the TMP of the SB6 tests. The figure shows that the TMP for each test was relatively similar and constant. Figure $4-7$ shows the measured turbidity of the filtrate measured 
SRNL-STI-2012-00523

SRNL-L3100-2012-00096

Revision 0

at various durations of each filter test. The turbidity measurements (all less than 2 NTU) indicate that the SB6 slurry was effectively filtered. Note that a mid-test turbidity measurement during the SVB6-14C test resulted in a value greater than 1 NTU, where all other measurements are less than 1 NTU. The turbidity dropped to a value comparable to the other filters later in the test. The reason for the relatively high turbidity is unknown. Regardless, turbidity less than 2 NTU met expectation for RMF performance.

As before, the shortened ORNL tests are a result of testing problems with the thick coupons. Once the ideal gasket configuration was found the questionable SB6 tests were repeated, however, task schedule considerations prompted shorter test durations in some cases. The SB6 tests presented in this section met the criteria of no blockage and good cake patterns.

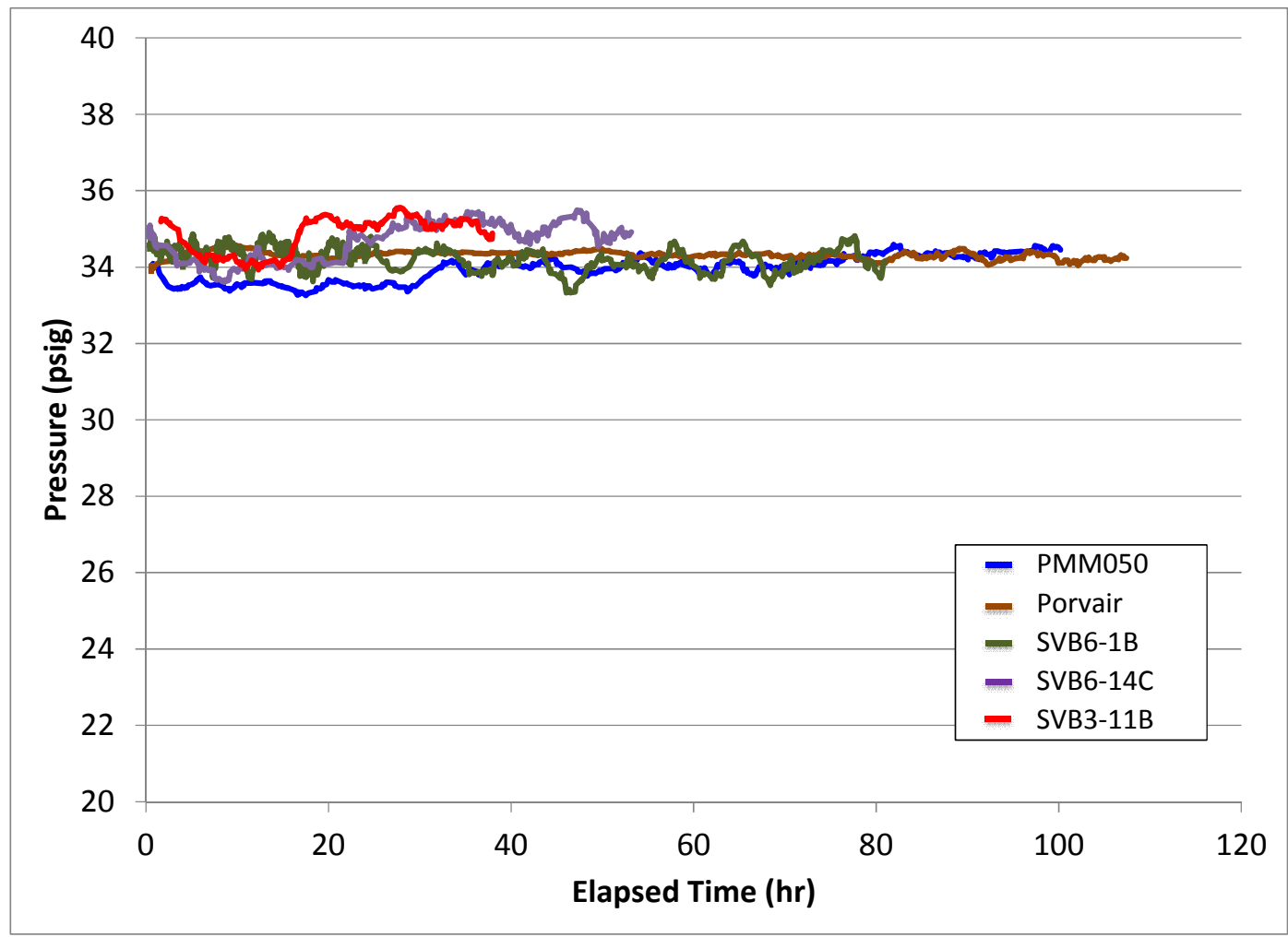

Figure 4-6: Transmembrane Pressure, SB6 Tests 
SRNL-STI-2012-00523

SRNL-L3100-2012-00096

Revision 0

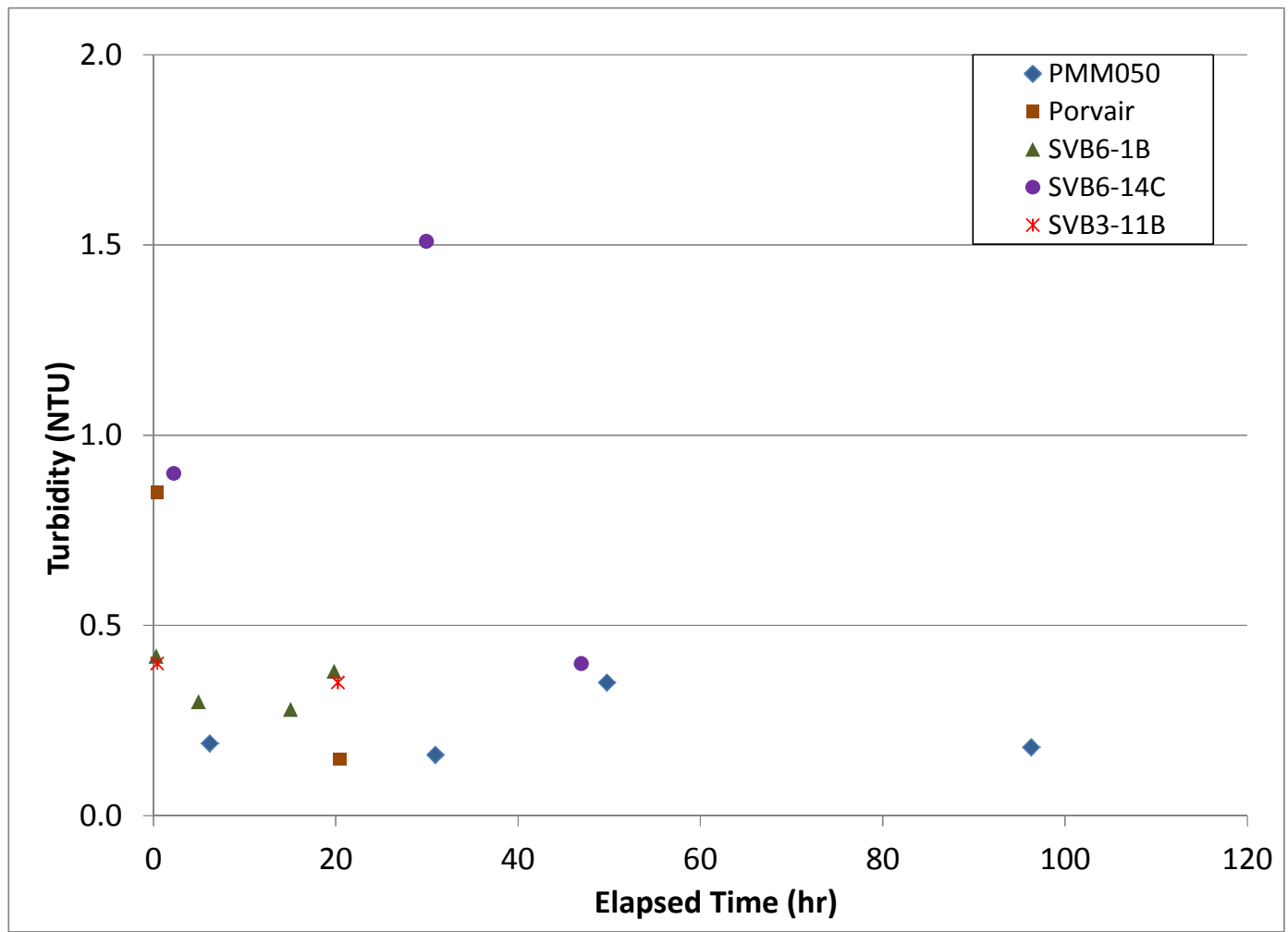

Figure 4-7: Filtrate Turbidity, SB6 Tests

\subsection{Conclusions}

The following conclusions were made from the STC testing.

- The Porvair $3 \mu$ filter performed best with MST slurry. It was $15-31 \%$ better than the next filter, the baseline Pall PMM050 filter.

- The ORNL SVB6-1B filter performed best with SB6 slurry. It was 7-21\% better than the next filter, the ORNL SVB3-11B, and 22-38\% better than the baseline Pall PMM050 filter.

- All of the coupons effectively filtered the 1 weight \% MST and SB6 slurries to provide a filtrate with a turbidity of less than 2 NTU.

- The STC was modified to successfully test filters thicker than 0.005 " using an additional gasket for the cell.

- Filter performance can be affected by STC operating conditions such as feed tank mixing, feed flow and TMP. Care was taken to maintain consistent condition throughout testing.

\subsection{Recommendations}

The following recommendation is suggested.

- The MST tests with ORNL filters should be repeated using the additional gasket to verify the results obtained with prior gasket configurations. The concern was that the ORNL filters may not have been seated properly on the bottom plate of the STC and the flow through the cell may not have been prototypic. 
SRNL-STI-2012-00523

SRNL-L3100-2012-00096

Revision 0

\subsection{References}

1. M. R. Poirier, D. T. Herman, R. Behave, "Evaluation of Alternative Filter Media for the Rotary Microfilter”, SRNL-STI-2011-00522, rev. 0, September, 2011.

2. D. T. Herman, M.R. Poirier, "Recipe for Simulated Sludge Batch 6-DS for Rotary Filter Testing,” SRNL-TR-2009-00111, Rev. 1, October, 2009.

\subsection{Appendices}

1. MST Test Difficulties 
SRNL-STI-2012-00523

SRNL-L3100-2012-00096

Revision 0

\section{Appendix 1 - MST Test Difficulties}

The STC was designed to test filter membranes with a thickness of 0.005 " or less. This thickness was required to seal the STC cell. As seen in Figure 8-1 of the bottom plate, the filter coupon laid on top of the inner O-ring and prevented a concentrate leak into the filtrate. The outer O-ring sealed the plates to prevent a filtrate leak from the cell.
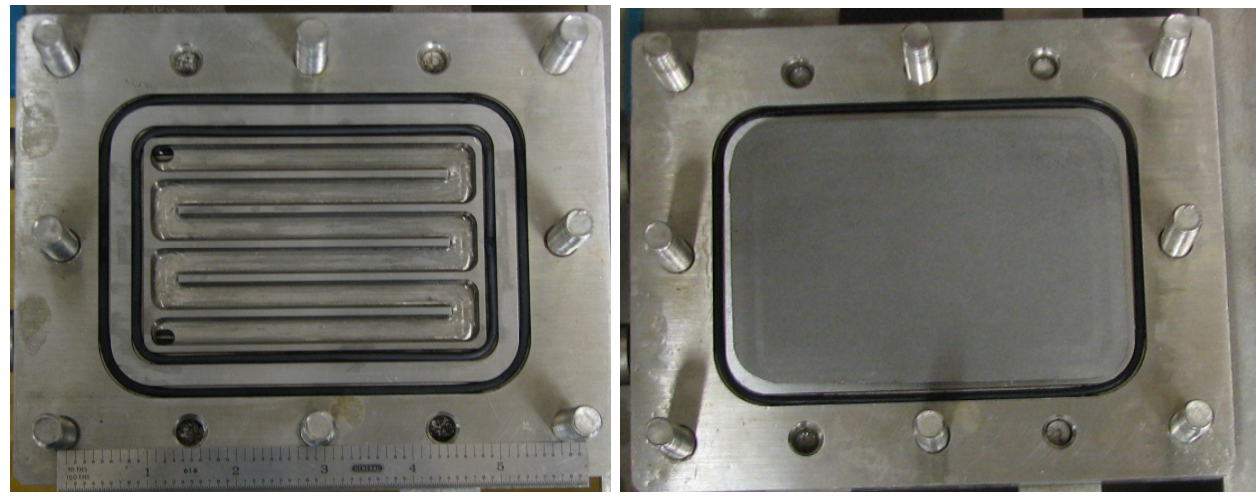

Figure 8-1. Filter Coupon on Bottom Plate

The thickness of the O-rings and the depth of their corresponding grooves allowed the O-rings to protrude out of the groove 0.015 inches. This provided sufficient compression of the O-rings. In high pressure applications, an O-ring compression of $20-30 \%$ is recommended. At the recommended coupon thickness of 0.005 " the outer O-ring compression was only $10 \%$, but this was sufficient at the lower operating pressures of the STC. In reality, the Pall coupon was 0.004" thick (which provided a $12 \%$ compression), and the Porvair was 0.012 " thick (which provided only 3\% compression). Neither the Pall nor the Porvair leaked with these compressions. Coupons 0.015 " or thicker would not allow the outer O-ring to seal. The ORNL filter coupons were, on average, 0.065 " thick (SVB6-14C 0.068" nominal, SVB6-1B 0.060" nominal, SVB311B 0.069 " nominal). An additional gasket was necessary to seal the cell when using ORNL filters.

For phase 1 testing [1] a thick (0.125"), flat gasket was used to provide a seal for the ORNL filters in the cell plates. The flat gasket was cut to fit to the outer edges of the cell plates with a rectangular hole in the middle to permit permeate flow through the coupon. The rectangular hole was slightly smaller than the coupons. The part of the gasket that overlapped the coupon provided a seal between the coupon and top plate, and the outer portion of the gasket provided a seal between the top and bottom plates (the inner O-ring maintained the seal between the coupon and the bottom plate). However, the overlapping portion required significant compression in order for the outer portion to seal the cell. In some instances this did not occur and the cell leaked. Leakage became a problem because over an extended and unattended period (over a weekend) the leak would drain a relatively significant portion of the feed tank.

To resolve the leaking problem several different flat gasket configurations were tried. First, the original flat gasket ( 0.125 " thick) was modified by increasing the size of the hole to fit snuggly around the ORNL coupons. The modified gasket can be seen in Figure 8-2. In order for this configuration to succeed the flat gasket must be compressed thinner than the ORNL coupon, 
SRNL-STI-2012-00523

SRNL-L3100-2012-00096

Revision 0

otherwise the coupon would not seal on the inner O-ring. Although very pliable, the flat gasket did not compress sufficiently to provide a seal. During operation concentrate side pressure would lift the coupon off of the bottom plate and allow flow over the channel walls. Flow over the channel walls was undesirable in that the velocity along the filter and the effective area of the filter were atypical. Consequently, as flow preferentially went over the channel walls, solids collected in low flow areas of the channel $\left(180^{\circ}\right.$ turns $)$ and eventually plugged the channel. Figure 8-3 shows two cake patterns that indicated a problem. The first picture shows cake on top of the channel walls and over the inner O-ring due to the filter lifting. The second picture is of a test where several channels were blocked with solids in the $180^{\circ}$ turns.
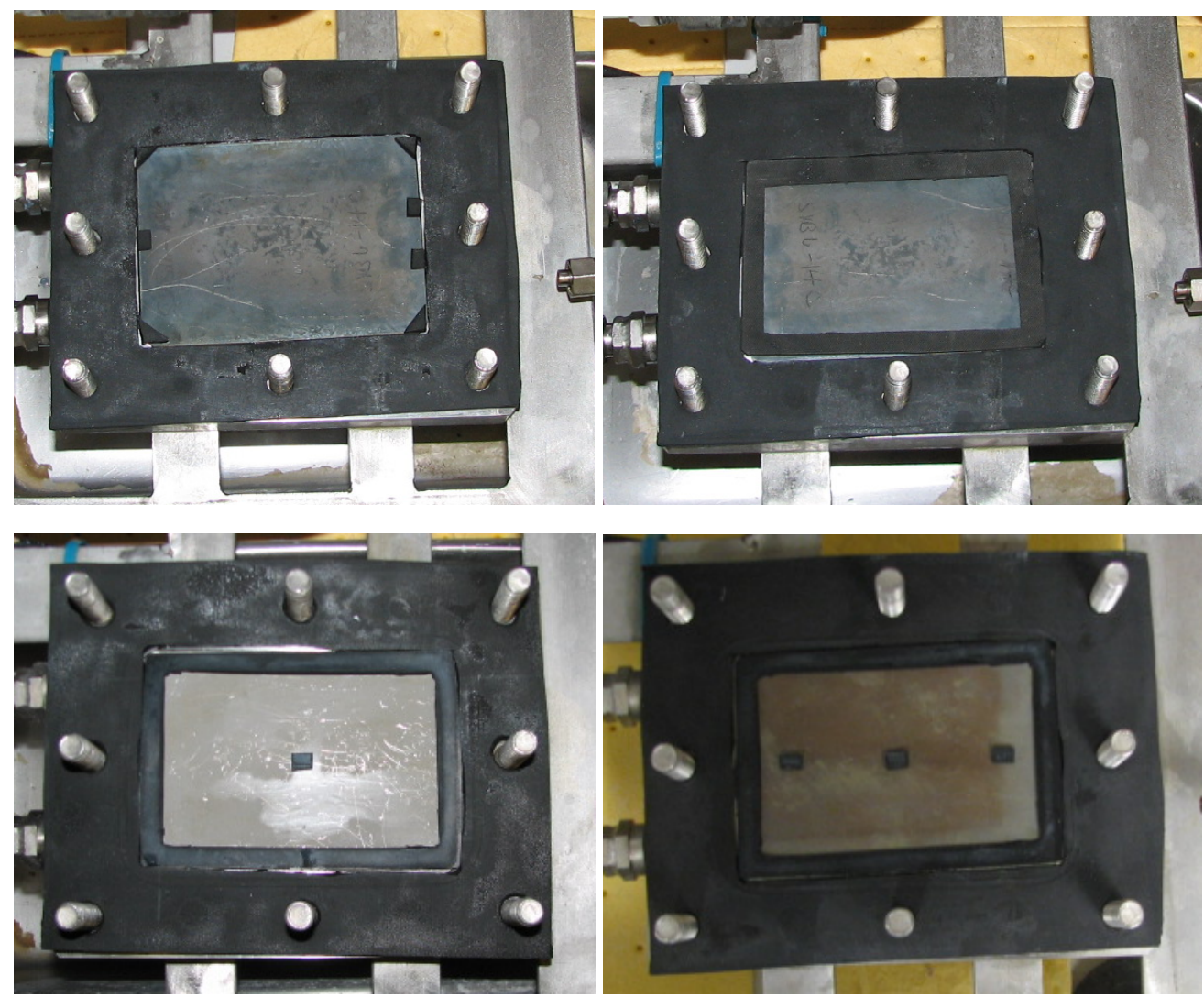

Figure 8-2. Gaskets at Edge and Center to Aid Sealing
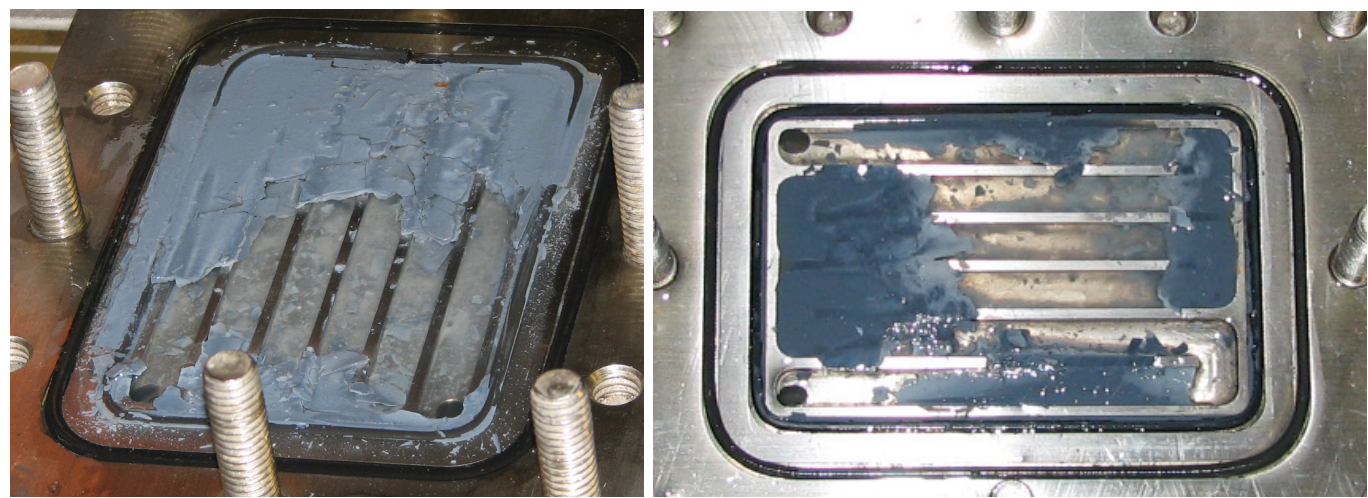

Figure 8-3. Bad Cake Patterns 
SRNL-STI-2012-00523

SRNL-L3100-2012-00096

Revision 0

Next, small pieces of 0.125 " thick gaskets were placed on top of the coupon in the corners and along the sides to press down on the coupon when assembled (Figure 8-2, top left). The pieces were intentionally small to avoid interference with the filtrate flow through the coupon. This method did not work as blockage in the turns was again evident after a test. To provide a more uniform force along the perimeter of the coupon an addition flat gasket, made from 0.065 " thick material, was used instead of the pieces (Figure 8-2, top right). Again, blockage in the turns was evident after the test. It was then discovered that some the ORNL filters were not perfectly flat, that is, a few filters had some degree of curvature along their length or width. In some cases the curvature created a gap between the bottom cell plate and the filter, which allowed feed to flow over the top of the channel walls (see Figure 8-4). To force the filter down on the bottom plate small pieces of gasket were placed in the center of the filter (Figure 8-2, bottom left and right). However, blockage in the turns was evident after the test indicating that the arrangement was not working as expected.

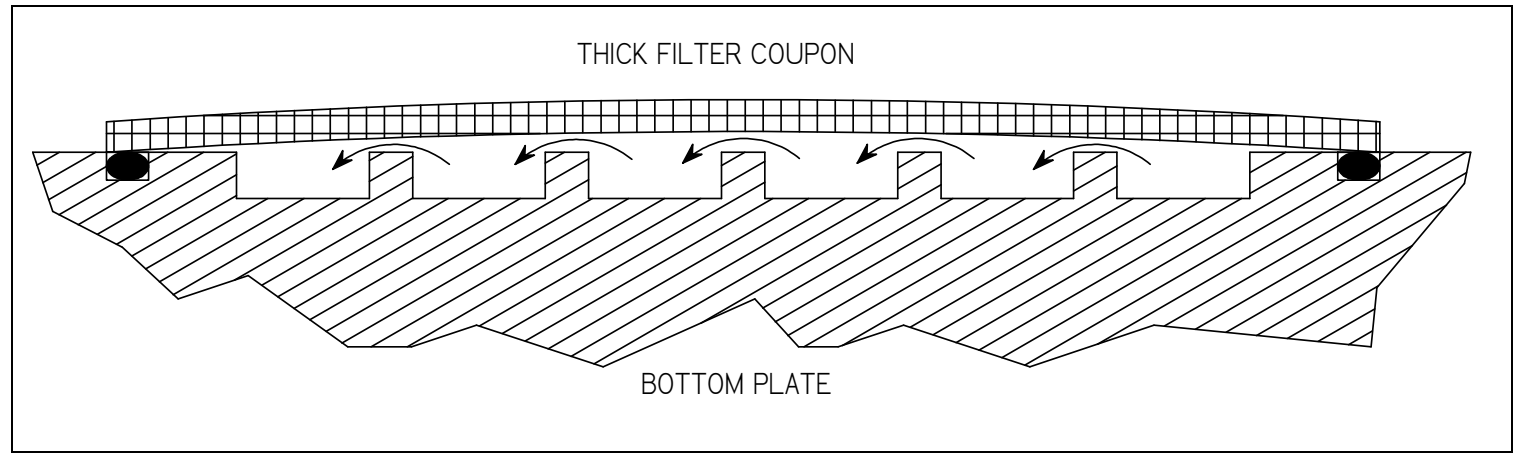

Figure 8-4. Effects of a Bowed Filter in the STC

The final and successful configuration was a thinner flat gasket to replace the thick flat gasket (see Figure 8-5). The thinner gasket was 0.080" thick and did not extend to the edges of the plates. The thinner gasket would compress enough to provide a seal between the plates and allow the top plate to press against the coupon and seat it on the bottom plate. This configuration provided tests without plugged channels and good cake patterns.

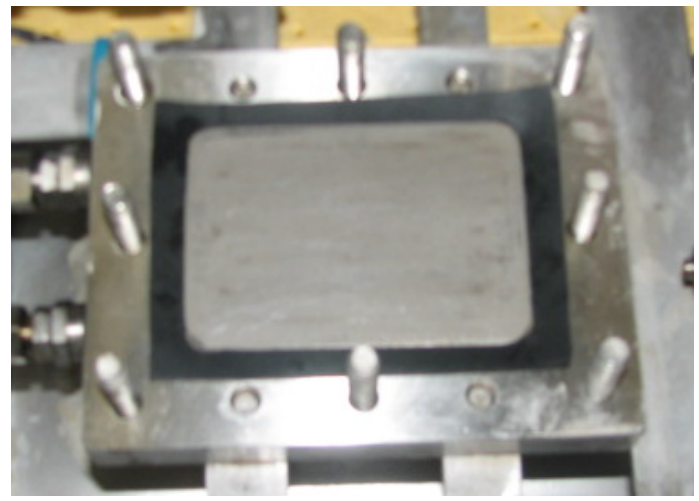

Figure 8-5. Final Gasket Configuration for ORNL Filters 
SRNL-STI-2012-00523

SRNL-L3100-2012-00096

Revision 0

\section{Distribution:}

D.A. Crowley, 773-43A

A. P. Fellinger, 773-42A

S. D. Fink, 773-A

K. M. Fox, 999-W

B. J. Giddings, 786-5A

C. C. Herman, 999-W

S. L. Marra, 773-A

A. M. Murray, 773-A

F. M. Pennebaker, 773-A

W. R. Wilmarth, 773-A

P. R. Jackson, DOE-SR, 703-46A

K. H. Subramanian, 766-H

D. T. Herman, 735-11A

M. R. Poirier, 773-42A

C. A. Nash, 773-42A

D. M. Patel, 241-102F

H. Huber, Hanford

R. Bhave, ORNL 